\title{
КЛИНИКО-БИОХИМИЧЕСКИЕ АСПЕКТЫ КОМПЛЕКСНОЙ ТЕРАПИИ ОСЛОЖНЕННЫХ ФОРМ ХРОНИЧЕСКОЙ ВЕНОЗНОЙ НЕДОСТАТОЧНОСТИ НИЖНИХ КОНЕЧНОСТЕЙ
}

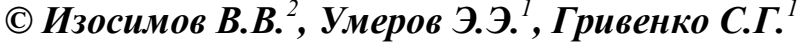

\author{
${ }^{1}$ Кафедра хирургии № $2,{ }^{2}$ кафедра хирургии № 1 Медицинской академии имени С.И. Георгиевского \\ Крымского федерального университета имени В.И. Вернадского, Симферополь \\ E-mail: 1zos2003@gmail.com
}

\begin{abstract}
Проведен сравнительный анализ результатов лечения 72 больных с осложненными формами хронической венозной недостаточности нижних конечностей, составивших две клинические группы, с изучением динамики уровней C-реактивного белка. Первую группу составили 52 пациента, у которых дополнительно в комплексном лечении трофических язв применялись оротат магния и энтеросорбция, вторую - 20 больных, не получавших предлагаемую дополнительную терапию. Эффективность проводимого лечения оценивали по клиническим параметрам - срокам очищения ран, появлением грануляций, эпителизации и биохимическим - определением уровней С-реактивного белка. Доказана эффективность сочетанного применения препаратов магния и энтеросорбции, позволяющая ускорить процесс заживления и сократить сроки пребывания больных в стационаре, а мониторинг уровня С-реактивного белка явился объективным критерием эффективности проводимого комплексного лечения.
\end{abstract}

Ключевые слова: трофические язвы, хроническая венозная недостаточность, С-реактивный белок.

\section{CLINICAL AND BIOCHEMICAL ASPECTS OF COMPLEX THERAPY OF COMPLICATED FORMS OF CHRONIC VENOUS INSUFFICIENCY OF LOWER EXTREMITIES Izosimov V.V. ${ }^{2}$, Umerov E.E. ${ }^{l}$, Grivenko S.G. ${ }^{l}$}

${ }^{1}$ Department of Surgery N 2, ${ }^{2}$ Department of Surgery N 1 of Medical Academy named after S.I. Georgievsky of Crimean Federal University named after V.I. Vernadsky, Simferopol

A comparative analysis of the results of managing 72 patients with complicated forms of chronic venous insufficiency of the lower limbs, who formed two clinical groups, and with the study of the dynamics of C-reactive protein level was conducted. The first group of 52 patients took the magnesium orotate and enterosorption in addition to the complex treatment of trophic ulcers. The second group included 20 patients who did not receive the proposed additional therapy. The effectiveness of the treatment was assessed by the clinical parameters - the timing of wound cleansing, the appearance of granulations, epithelization and the biochemical ones - determination of C-reactive protein levels. The effectiveness of the combined use of magnesium preparations and enterosorption has been proved, which makes it possible to accelerate the healing process and shorten the length of stay at hospital. Monitoring the C-reactive protein level was an objective criterion of the effectiveness of the complex treatment.

Keywords: trophic ulcers, chronic venous insufficiency, C-reactive protein.

Хроническая венозная недостаточность (XBH) - одна из наиболее распространенных патологий. По данным Международного союза флебологов, эта патология встречается почти у 60\% людей [3]. Трофические язвы (ТЯ) являются тяжелым осложнением ХВН и поражают до 5\% работоспособного населения $[2,17]$. В 12,5\% случаев пациенты с венозными ТЯ вследствие снижения трудоспособности вынуждены преждевременно прекращать трудовую деятельность [6]. В экономически развитых странах на лечение таких больных затрачиваются огромные материальные средства, составляющие от 1,5 до $2 \%$ общего бюджета здравоохранения [15]. Несмотря на значительные достижения последних лет в диагностике и лечении ХВН, частота развития ТЯ не имеет достоверной тенденции к снижению. Эти обстоятельства заставляют обозначить проблему лечения ТЯ не только как медицинскую, но и социально значимую [16].
Современная программа лечения ТЯ венозной этиологии базируется на принципе этапности и рационального сочетания компрессионного, хирургического и медикаментозного лечения с учетом стадии ХВН, превалирующего синдрома и наличия осложнений [7].

В последнее время появились работы, доказывающие положительную роль энтеросорбентов в лечении осложненных форм варикозной болезни [1]. Лечебная эффективность энтеросорбции зависит и от ряда факторов, в том числе от направленности лечебного действия сорбента, который используется. Особый интерес, на наш взгляд, представляет диоктаэдрический смектит (ДЭС). ДЭС относится к числу сорбентов, высоко стандартизированных по сырью, из которого его получают; имеет прочную полимерную кремнеорганическую основу, содержащую в качестве гетероатомов алюминий и магний, координирующих вокруг себя ОН-группы. Пористая структу- 
ра обеспечивает «мягкость» действия ДЭС и совместимость при контакте с биологическими средами [14]. Содержащийся в ДЭС магний также важен для процессов репарации. Магний является модулятором роста соединительной ткани, а препараты магния могут быть весьма полезны для оптимизации процессов ранозаживления [13].

В то же время раневой процесс - это совокупность молекулярных и клеточных процессов, последовательно происходящих в ране и направленных на репарацию поврежденной ткани с восстановлением ее целостности. При оценке течения раневого процесса принципиальное значение имеет объективная оценка эффективности репаративных процессов на определенных стадиях заживления. Кроме традиционной топографоанатомической и морфологической характеристики раны для диагностики и прогнозирования течения раневого процесса применяют микробиологические и биохимические исследования. Полнота участия определенных молекулярных и клеточных компонентов определяет скорость заживления, поэтому анализ ключевых участников этого процесса позволяет количественно оценить эффективность репаративных процессов [10]. Одним из таких маркеров традиционно считают С-реактивный белок (СРБ). СРБ - это мультифункциональный белок острой фазы, играющий важную роль при воспалениях, защите от чужеродных агентов и в аутоиммунных процессах. Он один из основных участников острой фазы воспаления: при воспалительном процессе его концентрация в крови увеличивается в 10-100 раз [9]. СРБ играет важную роль в клиренсе организма от бактерий, погибших и поврежденных клеток. Кроме того, последующее снижение сывороточной концентрации СРБ по мере разрешения воспаления может оказаться полезным для мониторирования эффективности проводимой терапии [8].

Цель исследования: оптимизация результатов лечения больных с венозными ТЯ посредством включения в комплексное лечение энтеросорбции и оротата магния с мониторированием ее эффективности динамикой уровней СРБ.

\section{МАТЕРИАЛЫ И МЕТОДЫ ИССЛЕДОВАНИЯ}

Проанализированы результаты обследования и комплексного лечения 72 пациентов с XВН С6 класса по СЕАР, находившихся на лечении в хирургических отделениях клинических баз МА им. С.И. Георгиевского КФУ им. В.И. Вернадского в период с 2012 по 2016 год. Все больные были поделены на 2 группы. Первую (основную) группу составили 52 пациента, у которых дополнительно в комплексном лечении ТЯ применялись оротат магния и энтеросорбция ДЭС $[11,12]$. При назначении базисной терапии, а именно препаратов диосминового ряда, дезагрегантов, противоотечной терапии и компрессионного трикотажа, больным дополнительно назначали оротат магния. Последний больные принимали по 2 таблетки $(1000$ мг) 3 раза в сутки в течение 7 дней, затем по 1 таблетке (500 мг) 2-3 раза в день. Продолжительность курса составляла не менее 4-6 недель. Исходя из состояния больного возможно назначение повторных курсов лечения. В качестве препарата, содержащего ДЭК, использовали энтеросорбент «Бента» (рис. 1), разработаный на основе Крымской голубой глины. Он обладает адсорбционными, мукопротекторными и цитопротекторными свойствами. Мукопротективный эффект диасмектита обусловлен его способностью защищать слизистую оболочку желудочно-кишечного тракта, образуя поливалентные связи с гликопротеидами слизи, связываясь с поврежденными участками, восстанавливая целостность надэпителиального слизистого слоя, увеличивая его массу, вязкость и защитные свойства [4]. Лекарственное средство «Бента» назначали в комплексной терапии в дозе 3 грамма трижды в день за 30 минут до приема пищи. Для этого больные содержимое пакета с «Бента» растворяли в 100 мл теплой питьевой воды, тщательно перемешивали и принимали внутрь. Курс приема составлял 7 дней.

Средний возраст пациентов этой группы составил $62,80 \pm 1,52$ года. Вторую (контрольную) группу составили 20 больных, не получавших предлагаемую дополнительную терапию. Средний возраст пациентов этой группы $61,58 \pm 2,07$ года. По демографическим показателям между основной и контрольной группами пациентов статистические различия отсутствовали. В обеих группах преобладали женщины 42 (58,33\%). Так же исследуемые группы больных были сопоставимы по наличию у пациентов сопутствующих заболеваний. Причиной развития XBH у $47(65,28 \%)$ пациентов была варикозная болезнь, а у $25(34,72 \%)$ - посттромбофлебетическая болезнь. В обеих группах для местного лечения применяли многокомпонентные антибактериальные водорастворимые мази. Эффективность проводимого лечения оценивали по клиническим параметрам - срокам очищения ТЯ, появлением грануляций, эпителизации, изменением интенсивности болевого синдрома, регистрировали наличие или отсутствие побочных эффектов лечения.

Содержание СРБ в сыворотке крови больных определяли «сэндвич»-вариантом тИФА с использованием биотин-стрептавидиновой системы усиления сигнала [5]. 


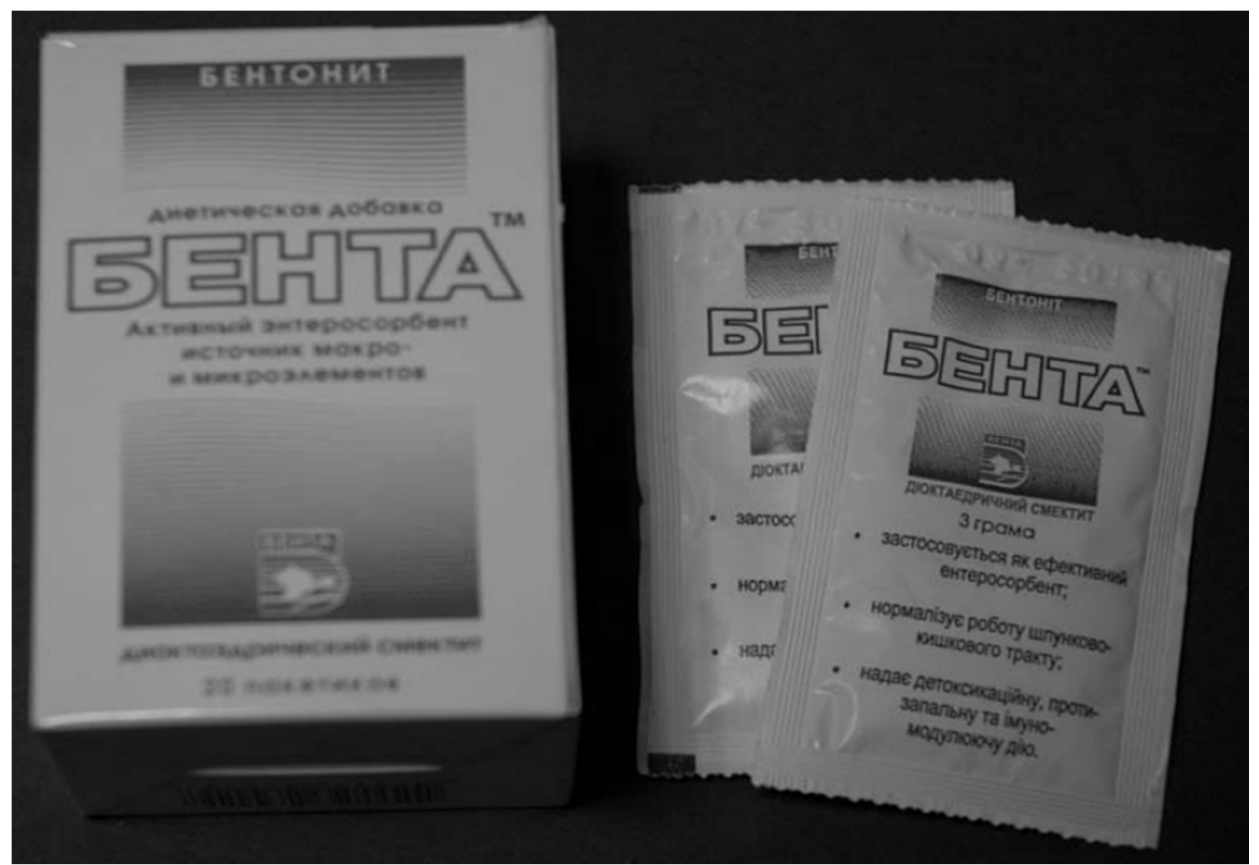

Рис. 1. Энтеросорбент «Бента».

Для получения слоя иммуносорбента в лунки полистироловых планшетов (Costar 9017, USA) вносили по 100 мкл раствора очищенной фракции $\mathrm{IgG}$, специфичных к СРБ человека (5 мкг/мл) в $0,01 \mathrm{M}$ фосфатном буфере (pH 7,4), содержащем $1 \% \mathrm{NaCl}$ (PBS) и инкубировали в течение 12 часов при комнатной температуре $\left(18-22^{\circ} \mathrm{C}\right)$. Для удаления не связавшихся антител и блокирования свободных центров связывания лунки промывали 3 раза по 1 мин PBS, содержащим $0,05 \%$ Twwen-20 (PBS-T). Затем в лунки последовательно вносили по 100 мкл разведенной сыворотки крови; биотинилированных антител к СРБ (1:5000); коньюгата стрептавидин-пероксидаза (1:10000, Sigma Chem. Co., USA) и инкубировали в течение 30 минут при комнатной температуре. Для разведения реагентов применяли PBS-T. Неспецифически связавшиеся компоненты после каждого этапа отмывали PBS-T (3 раза по 1 мин). Для регистрации пероксидазной активности в лунки вносили по 100 мкл субстратно-буферной смеси (30 мМ фосфатно-цитратный буфер (pH $5,0)$, содержащий 0,33 мг/мл о-фенилендиамина и $0,02 \% \mathrm{H}_{2} \mathrm{O}_{2}$ ) и инкубировали 15 мин при комнатной температуре. Реакцию останавливали прибавлением в лунки 25 мкл $3 \mathrm{M}$ серной кислоты. Оптическую плотность конечного продукта ферментативной реакции определяли с помощью иммуноферментного анализатора StatFax 2100 (Awareness Tech. Inc., USA) при длине волны 492 нм. Для построения калибровочной кривой, необходимой для количественного определения концентрации СРБ в обследуемых образцах крови, использовали коммерческий стандарт СРБ человека (ООО «Микрофлора» при МНИИ им. Г.Н. Габричевского, Россия). Содержание СРБ выражали в мкг/мл.

Материалом для биохимических исследований служила сыворотка крови 44 больных обеих клинических групп: 24 первой (основной) и 20 второй (контрольной), полученная общепризнанным способом при поступлении, через 7 и 14 суток от начала лечения. Каждый пациент получал подробную информацию о проводимом исследовании и давал информированное согласие на участие в исследовании. Контролем служила группа практически здоровых лиц (14 чел.).

Статистическая обработка полученных данных проведена с применением методов вариационной статистики с вычислением средних величин (M), оценкой вероятности расхождений (m), оценкой достоверности изменений с использованием t-критерия Стьюдента. За достоверную принималась разность средних значений при $\mathrm{p}<0,05$.

\section{РЕЗУЛЬТАТЫ ИССЛЕДОВАНИЯ И ИХ ОБСУЖДЕНИЕ}

В результате применения предложенного комплексного лечения раневого процесса на нижних конечностях у больных с XВН показатели клинической эффективности существенно улучшились. Они представлены в таблице № 1.

При этом было установлено, что в основной группе быстрее происходило купирование воспалительных явлений, уменьшение отека, болей. Больные субъективно отмечали улучшение самочувствия. Очищение раны и наступление грануляционной фазы раневого процесса так же в основной группе происходило быстрее, чем 
Лечебная эффективность комплексного лечения трофических язв при хронической венозной недостаточности

\begin{tabular}{|c|c|c|c|c|c|}
\hline Группа больных & $\mathrm{n}$ & $\begin{array}{c}\text { Сроки } \\
\text { очищения ран } \\
\text { (сутки) }\end{array}$ & $\begin{array}{c}\text { Сроки появления } \\
\text { грануляций } \\
\text { (сутки) }\end{array}$ & $\begin{array}{c}\text { Сроки начала } \\
\text { эпителизации } \\
\text { (сутки) }\end{array}$ & $\begin{array}{c}\text { Средний койко- } \\
\text { день } \\
\text { (сутки) }\end{array}$ \\
\hline Основная & 52 & $6,17 \pm 0,24$ & $9,52 \pm 0,33$ & $13,06 \pm 0,37$ & $16,89 \pm 0,42$ \\
\hline Контрольная & 20 & $8,95 \pm 0,40$ & $14,20 \pm 0,50$ & $17,20 \pm 0,45$ & $21,75 \pm 0,55$ \\
\hline
\end{tabular}

Таблица 2

Показатели уровня С-реактивного белка у больных с трофическими язвами на фоне комплексной терапии

\begin{tabular}{|c|c|c|c|}
\hline Группа больных & $\mathrm{n}$ & Сроки наблюдения & $\begin{array}{c}\text { Уровень СРБ, } \\
\text { мг/л }\end{array}$ \\
\hline \multirow{3}{*}{ Первая } & \multirow{3}{*}{24} & Поступление & $11,37 \pm 0,97$ \\
\hline & & 7 сутки & $7,59 \pm 0,68$ \\
\hline & & 14 сутки & $3,84 \pm 0,38$ \\
\hline \multirow{3}{*}{ Вторая } & \multirow{3}{*}{20} & Поступление & $11,84 \pm 1,06$ \\
\hline & & 7 сутки & $8,63 \pm 0,82$ \\
\hline & & 14 сутки & $6,39 \pm 0,49$ \\
\hline Контроль & 14 & & $0,82 \pm 0,09$ \\
\hline
\end{tabular}

Примечание: в динамике лечения внутри групп различия достоверны на 7 и 14 сутки по сравнению с показателями при поступлении $(\mathrm{p}<0,05)$.

в контрольной $(\mathrm{p}<0,05)$. Так, в основной клинической группе наблюдалось наиболее быстрое очищение ран по отношению к контрольной $(6,17 \pm 0,24$ против $8,95 \pm 0,80)$. Аналогичные тенденции наблюдались и в дальнейшем. Так, средние сроки появления грануляций с наиболее ранними терминами отмечались в основной клинической группе. Эти показатели были меньше, чем в контрольной группе на 4,68 суток $(9,52 \pm 0,33$ против $14,20 \pm 0,50)$. Такие же тенденции сохраняются и при оценке средних сроков начала эпителизации. Наиболее ранние сроки отмечались в основной клинической группе и составили $13,06 \pm 0,37$, что на 4,14 суток меньше, чем у больных контрольной группы - 17,20 $\pm 0,45$. Эти тенденции позволили уменьшить средний койко-день у больных основной клинической группы до $16,89 \pm 0,42$, что на 4,86 суток менее, чем в контрольной группе $-21,75 \pm 0,55$.

Поскольку концентрация СРБ в ответ на воспаление быстро возрастает, он играет важную роль в клиренсе организма от бактерий, погибших и поврежденных клеток. Этот аспект представляется полезным в экспресс-диагностике, так как прогрессивное увеличение его концентрации может быть установлено уже в первые сутки от начала заболевания. Кроме того, последующее снижение сывороточной концентрации СРБ по мере разрешения воспаления может оказаться полезным для мониторирования эффективности проводимого лечения, что и послужило основанием для нашего исследования.
Показатели уровня СРБ у больных с ТЯ и гнойно-некротическими ранами на фоне комплексной терапии представлены в таблице № 2 . Было установлено, что начальный фон уровня СРБ был значительно повышен во всех группах больных по отношению к контролю. У больных с ХВН он превышал контрольные показатели более чем в 14 раз $(11,84 \pm 1,06$ против $0,82 \pm 0,09)$. В процессе лечения отмечено снижение уровней СРБ также во всех клинических группах больных. Однако у больных второй клинической группы процесс стабилизации концентрации СРБ носил менее выраженный характер. Динамика уменьшения уровней СРБ прослеживалась уже, начиная с 7 суток комплексной терапии во всех группах больных. Так, у больных первой клинической группы отмечено существенное снижение уровней СРБ по отношению к начальному фоновому на $33 \%(11,37 \pm 0,97$ против $7,59 \pm 0,68)$. В то же время у больных второй клинической группы это снижение носило менее выраженный характер на $27 \%(11,84 \pm 1,06$ против $8,63 \pm 0,82)$.

Аналогичные тенденции наблюдались и к 14 суткам. Так, у больных первой клинической группы к 14 суткам отмечено снижение уровней СБР по отношению к начальному фоновому на $66 \%(11,37 \pm 0,97$ против $3,84 \pm 0,38)$. У больных же второй клинической группы это снижение носило менее выраженный характер, а именно около $46 \%$

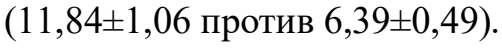

Во всех клинических группах к 14 суткам уровни СРБ так и не достигли уровня контроля (нормы). Эти данные свидетельствуют о том, что 
воспалительные изменения в организме больных с ТЯ и гнойно-некротическими ранами венозного генеза полностью не купируются к этому сроку. Однако определение уровня СРБ явилось объективным критерием эффективности проводимого комплексного лечения. Включение же в комплексную терапию ДЭК и репаранта позволило существенно снизить уровень СРБ уже в ранние сроки лечения, а это обстоятельство способствовало ускорению выздоровления больных и сокращению сроков стационарного лечения.

Таким образом, применение предложенной комплексной терапии трофических нарушений при ХВН позволяет ускорить процессы репарации и сократить сроки лечения. Определение динамики уровня СРБ может быть адекватным маркером репаративных процессов при ТЯ венозного генеза и применяться как прогностический критерий эффективности их лечения.

\section{ЛИТЕРАТУРА}

1. Біляєва О.О., Коржик Н.П., Миронов О.М., Балінська M.І., Смець В.В. Роль ентеросорбентів у лікуванні ускладненої варикозної хвороби // Клінічна хірургія. - 2014. - № 6. - С. 43-45.

2. Богачев В.Ю. Диагностика и лечение хронических заболеваний вен. Обзор практического руководства Европейского общества сосудистых хирургов // Стационарозамещающие технологии: Амбулаторная хирургия. - 2015. -№ 3-4. - С. 6-11.

3. Богданец Л.И. Как можно предупредить образование и рецидив трофических язв у больных с варикозной болезнью // Стационарозамещающие технологии. - 2015. - № 1-2. - С. 20-25.

4. Буглак М.П., Чоботько Г.М., Тарикін Д.Н., Богданов М.М., Каладзе М.М., Мірошниченко Н.В., Коваленко О.М., Лавренчук Г.Й. Застосування полімінерального засобу природного походження «Бента $^{\mathrm{TM}}$ (Бентоніт)» при хронічних інтоксикаціях та метаболічних розладах: Методичні рекомендації. Київ, 2008. - 27 с.

5. Гордієнко А.І., Білоглазов В.О., Бакова А.А. Високочутливий імуноферментний метод кількісного визначення змісту С-реактивного білка в крові : Інформаційний лист. - Київ : Укрмедпатентінформ, 2010. - 4 с.

6. Карапетян Г.Э., Якимов С.В., Микитин И.Л., Кочетова Л.В., Пахомова Р.А. Современный метод ведения трофических язв // Фундаментальные исследования. - 2013. - № 9. - С. 1016-1018.

7. Круглова Л.С., Панина А.Н., Стрелкович Т.И. Трофические язвы венозного генеза // Российский журнал кожных и венерических болезней. - 2014. № 1. - С. 21-25.

8. Носков С.М., Василевская О.А., Носкова Т.С., Арзиманова Н.А. Значение С-реактивного белка при системной красной волчанке // Клиницист. 2012. - № 1. - С. 10-14.
9. Палеев Ф.Н., Белокопітова И.С., Москалец О.В., Минченко Б.И. Информативность определения C-реактивного белка и неоптерина у пациентов с ишемической болезнью сердца // Альманах клинической медицині. - 2010. - № 23. - С. 76-79.

10. Петренко О.М., Безродний Б.Г., Тихомиров А.О. Моніторинг перебігу ранового процесу у гнійних ранах // Хірургія України. - 2014. - № 2. C. 65-69.

11. Спосіб консервативного лікування варикозної хвороби нижніх кінцівок : пат. 89297 Украина, МПК А61P 9/14 (2006.01) / С.Г. Гривенко, В.В. Ізосімов - № u2013 14404 ; заявлено 09.12.13 ; опубл. 10.04.14, Бюл. № 7. -4 с.

12. Спосіб лікування ускладненної варикозної хвороби нижніх кінцівок: пат. 112033 Украина, МПК (2016.01) А61K 9/14 (2006.01) А61К 33/00 A/61K 33/12 (2006.01) А61P 9/14 (2006.01) / І.Я. Дзюбановський, С.Г. Гривенко, В.В. Ізосімов. - № u2016 07157 ; заявлено 01.07.16 ; опубл. 25.11.16, Бюл. № 22. -4 c.

13. Суракова Т.В., Жидоморов Н.Ю., Гришина Т.Р., Кодин А.А., Чибисов И.В., Илларионов Е.Э., Коробова О.Р., Торшин И.Ю., Лепахина Л.Э., Громова O.A. Влияние оротатата магния на регенерацию кожи // Русский медицинский журнал. 2012. - № 11. - С. 575-581.

14. Урсова Н.И. Место энтеросорбентов в терапии синдрома эндогенной интоксикации // Вопросы современной педиатрии. - 2012. - № 11(6). C. $26-31$.

15. Eklof B., Perrin M., Delis K.T., Rutherford R.B., Gloviczki P.; American Venous Forum; European Venous Forum; International Union of Phlebology; American College of Phlebology; International Union of Angiology. Updated terminology of chronic venous disorders: the VEIN-TERM transatlantic interdisciplinary consensus document // J Vasc Surg. 2009. - Vol. 49, N 2. - P. 498-501. - doi: 10.1016/j.jvs.2008.09.014.

16. Rabe E., Guex J-J., Puskas A., Scuderi A., Fernandez Quesada F.; VCP Coordinators. Epidemiology of chronic venous disorders in geographically diverse populations: results from the Vein Consult Program // International Angiology. - 2012 - Vol. 31, N 2. P. 105-115.

17. Wittens C., Davies A.H., Bakgaard N., Broholm R., Cavezzi A., Chastanet S., de Wolf M., Eggen C., Giannoukas A., Gohel M., Kakkos S., Lawson J., Noppeney T., Onida S., Pittaluga P., Thomis S., Toonder I., Vuylsteke M., Kolh P., de Borst G.J., Chakfé N., Debus S., Hinchliffe R., Koncar I., Lindholt J., de Ceniga M.V., Vermassen F., Verzini F., De Maeseneer M.G., Blomgren L., Hartung O., Kalodiki E., Korten E., Lugli M., Naylor R., Nicolini P., Rosales A.; European Society for Vascular Surgery. Editor's Choice - Management of Chronic Venous Disease: Clinical Practice Guidelines of the European Society for Vascular Surgery (ESVS) // European Journal of Vascular et Endovascular Surgery. - 2015. - Vol. 49, N 6. - P. 678-737. doi: 10.1016/j.ejvs.2015.02.007. 